\title{
A population-based study on the incidence of inflammatory bowel disease in Oviedo (Northern Spain)
}

\author{
L. Rodrigo, S. Riestra ${ }^{1}$, P. Niño, V. Cadahía, R. Tojo, D. Fuentes, M. Moreno, E. González-Ballina, \\ and E. Fernández ${ }^{2}$
}

Service of Digestive Diseases. Hospital Universitario Central de Asturias. ${ }^{1}$ Section of Digestive Diseases. Hospital Valle del Nalón. Asturias. ${ }^{2}$ Department of Biochemistry. Hospital de Cabueñes. Gijón. Asturias, Spain

\begin{abstract}
Objective: to assess the incidence of inflammatory bowel disease in Oviedo (Northern Spain), and to describe the clinical features of new patients.

Patients and methods: a prospective population-based study was made at the Health Area IV, Principality of Asturias (Oviedo, 312,324 inhabitants). All new diagnosed patients with inflammatory bowel disease were registered over a 2-year period.

Results: a total of 85 patients were included, 47 of these with ulcerative colitis (UC), 37 with Crohn's disease (CD), and 1 with undetermined colitis. The overall adjusted incidence rate of UC and CD per $10^{5}$ inhabitants between 15-64 years was 9.1 (95\% CI: 5-13.1) and 7.5 (95\% CI: 3.8-11.2), respectively. The global male/female ratio was 0.9 , without significant differences between both diseases. $\mathrm{CD}$ patients were younger than those with UC ( $33 \pm 15$ years vs $45 \pm 20$ years; $p<0.05)$. Mostly, CD patients were diagnosed at an age younger than 35 years (65\%), while UC patients were diagnosed at an age between 25 and 64 years (81\%).

Disease extension in UC was proctitis in $11 \%$, left-side colitis in $53 \%$ and extensive colitis in $36 \%$. With respect to CD, the ileocolonic form predominated (49\%), followed by the ileal (40\%) and colonic (11\%) forms; an inflammatory, stenotic and fistulous pattern was seen in 54, 22 and $24 \%$ of patients, respectively.

Conclusions: in our area, the incidence of $\mathrm{CD}$ is similar to that in other Northern European countries, while UC has a lower incidence. CD mainly affects young people, while UC predominates in middle-aged patients. At diagnosis, UC is predominantly localized, the ileo-colonic form and an inflammatory pattern being most frequent in $\mathrm{CD}$ patients.
\end{abstract}

Key words: Inflammatory bowel disease. Ulcerative colitis (UC). Crohn's disease (CD). Incidence. Epidemiology. Spain.

Recibido: 08-10-03.

Aceptado: 10-11-03.

Correspondencia: Luis Rodrigo. Servicio de Aparato Digestivo. Hospital Universitario Central de Asturias. C/ Celestino Villamil, s/n. 33006 Oviedo. Tel.: + 34. (985) 1080 58. Fax: + 34. (985) 2736 14. e-mail: lrodrigos@terra.es
Rodrigo L, Riestra S, Niño P, Cadahía V, Tojo R, Fuentes D, Moreno $M$, González-Ballina E, Fernández E. A population-based study on the incidence of inflammatory bowel disease in Oviedo (Northern Spain). Rev Esp Enferm Dig 2004; 96: 296-304.

\section{INTRODUCTION}

Inflammatory bowel disease (IBD) is a generic term that classically includes Crohn's disease (CD), ulcerative colitis (UC), and undetermined colitis (UC). The causes of these diseases are not well known, but genetic predisposition and environmental factors are involved in their etiology and pathogenesis (1). In general, population studies have shown that the incidence of UC and CD is highest in northern latitudes (2-3); in addition, evidence exists for epidemiologic variability within countries (4). These differences may result from variations in the sociodemographic characteristics of populations (5), rather than from different genetic backgrounds. In Spain, several prospective population-based studies have shown a variable frequency of IBD (8-16 cases per 100.000 inhabitants/year) (6-8). These results are in agreement with the smaller-than-expected difference in North-versusSouth incidence of IBD, found by the European Collaborative Study on Inflammatory Bowel Disease (2).

Most incidence-oriented studies of IBD have been made in adults and there have been few population-based, prospective studies in children (9). Contradictory data exist on the time trend of juvenile-onset IBD incidence (9-11). In Spain, the incidence of IBD in children 14 years of age or younger is unknown.

At present, the management of patients with IBD is associated with substantial healthcare costs in terms of medical visits, hospitalization, surgery, chronic treatments, biologic therapies, etc. $(12,13)$. On the other hand, in view of the complexity of these diseases, a multidiscipli- 
nary approach (gastroenterologists, surgeons, dieticians,...) has been required, and monographic units have been created to attend to this type of patients. Therefore, in order to schedule health resources, it is of considerable interest that the incidence of IBD be known.

The objective of this study was to determine the incidence of IBD in the general population of Oviedo (Principality of Asturias, Spain), and to record the phenotypic characteristics of newly diagnosed patients during a twoyear period. Furthermore, clinical features of IBD in children are described.

\section{PATIENTS AND METHODS}

\section{Study design}

A prospective and descriptive study was undertaken in the general population $(312,324$ inhabitants, $75 \%$ in urban areas) of Health Area IV, Principality of Asturias (Northern Spain). The referral hospital for this population was "Hospital Universitario Central de Asturias" (Oviedo). The enrolment period spanned from September 2000 to September 2002.

A study protocol was established and sent to all general practitioners, pediatricians and Internal Medicine, Gastroenterology and Surgery specialists in Health Area IV. In addition, several informative meetings were held, before and during the period of the study. The objective was that all new patients with a suspected diagnosis of IBD, were sent to the referral center, for confirmation and registration.

\section{IBD patients}

All cases were evaluated at Hospital Universitario Central de Asturias in an outpatient clinic, devoted to patients with IBD (outpatients). Furthermore, patients who had been hospitalized for the first time because of suspected IBD, and were then diagnosed as new cases during the study period, were also included (inpatients). There was no age restriction.

At baseline, all subjects underwent a complete evaluation, including a collection of demographic and clinical data, physical examination and laboratory studies (blood cell count, coagulation tests, and biochemistry). Acutephase reactants such as erythrocyte sedimentation rate, reactive $\mathrm{C}$ protein and orosomucoid acid, were also measured. A colonoscopy and/or barium examination of the small bowel was performed, and intestinal biopsies were collected, in order to confirm the diagnosis and to assess disease extension. Based on the results of these studies, patients were registered as having or not IBD; the classical Lennard-Jones criteria for CD (14) and TrueloveWitts criteria for UC (15) were strictly applied. Follow-up visits were individually scheduled according to the each patient's clinical status.
In order to assess the intensity of symptoms, specific activity indexes were calculated at baseline and during each visit $(15,16)$. With the aim of describing the phenotypic expression of CD, we used the Vienna classification (17), which includes age at diagnosis ( $\mathrm{A} 1=$ below 40 years; $\mathrm{A} 2=$ equal to or above 40 years), location (L1 = terminal ileum; L2 = colon; L3 = ileocolon; L4 = upper gastrointestinal tract), and behavior (B1 = inflammatory; B2 = stricturing; B3 = penetrating).

\section{Statistical analysis}

One patient with undetermined colitis was excluded from the study. Mean annual CD and UC incidence rates were calculated as the number of new cases per 100,000 inhabitants per year. We used the direct method of standardization (European standard population) to adjust incidence rates for different ages (ten-year intervals) and genders. Confidence intervals (CI) for incidence rates were assessed with a $95 \%$ level of probability, by using a Poisson distribution or normal distribution. Truncated (15-64 yr) agestandardized incidence rates were used to compare our results with those in the European standard population. Proportions were compared using Fisher's exact test. Differences between groups were examined using a two-sided approach, with $\mathrm{p}<0.05$ considered as significant.

\section{RESULTS}

A total of 85 new patients were diagnosed as having IBD during the 2-year enrolment period, of whom 47 had $\mathrm{UC}, 37 \mathrm{CD}$ and 1 undetermined colitis. The ratio $\mathrm{UC} / \mathrm{CD}$ was 1.3 . Overall, 28 patients $(33 \%)$ were diagnosed during hospitalization as having severe gastrointestinal symptoms (inpatients), without differences between both processes. Forty patients were male (M) and 44 female $(\mathrm{F})$, with a $\mathrm{M} / \mathrm{F}$ ratio of 0.9 . Mean age was $39 \pm 18$ years (range 12-91 years), without significant differences when comparing the mean age of males $(36 \pm 17)$ versus females $(32 \pm 17)$. The baseline general characteristics of patients with IBD are shown in table I; on comparing patients with UC and CD, differences were only found for age (CD patients were younger than UC patients) $(\mathrm{p}<0.05)$.

The mean annual incidence rates of UC and CD were 7.5 and 5.9 per $10^{5}$ inhabitants, respectively. Figure 1 shows overall age and gender-specific incidence rates for both diseases. CD was diagnosed mostly in subjects younger than 35 years $(65 \%)$, with rates for both genders declining with increasing age; a small increase in incidence was observed in women at 45-54 years and in men at 55-64 years. For UC, different patterns of incidence were observed for both men and women, with an incidence peak at 25-34 years for women, whereas for men there were two incidence peaks, at 25-34 and 45-64 years. Table II shows the adjusted UC and CD incidence rate per 
Table I. General characteristics of patients with ulcerative colitis and Crohn's disease

\begin{tabular}{lcc}
\hline & $\begin{array}{c}\text { Ulcerative colitis } \\
(n=47)\end{array}$ & $\begin{array}{c}\text { Crohn's disease } \\
(n=37)\end{array}$ \\
\hline Age (yr) (mean \pm SD) & $45 \pm 20$ & $33 \pm 15^{*}$ \\
Gender & & \\
$\quad$ Male & 24 & 16 \\
Female & 23 & 21 \\
M/F ratio & 1 & 0.8 \\
Inpatients at diagnosis, n (\%) & $15(32)$ & $13(35)$ \\
Risk factors: & $9(19)$ & $8(22)$ \\
Tonsillectomy, n (\%) & $4(9)$ & $3(8)$ \\
Appendectomy, n (\%) & $19(40)$ & $17(46)$ \\
Smokers, n (\%) & $13(28)$ & $9(24)$ \\
NSAID users, $\mathrm{n}(\%)$ & $12(26)$ & $9(24)$ \\
Pill users, $\mathrm{n}(\%)$ & $1(2)$ & $4(11)$ \\
IBD in relatives, $\mathrm{n}(\%)^{*}$ & & \\
\hline
\end{tabular}

\section{${ }^{*} \mathrm{p}<0.05$}

yr: years; SD: standard deviation; M/F: male/female; NSAID: non-steroidal anti-inflammatory drugs; IBD: inflammatory bowel disease.
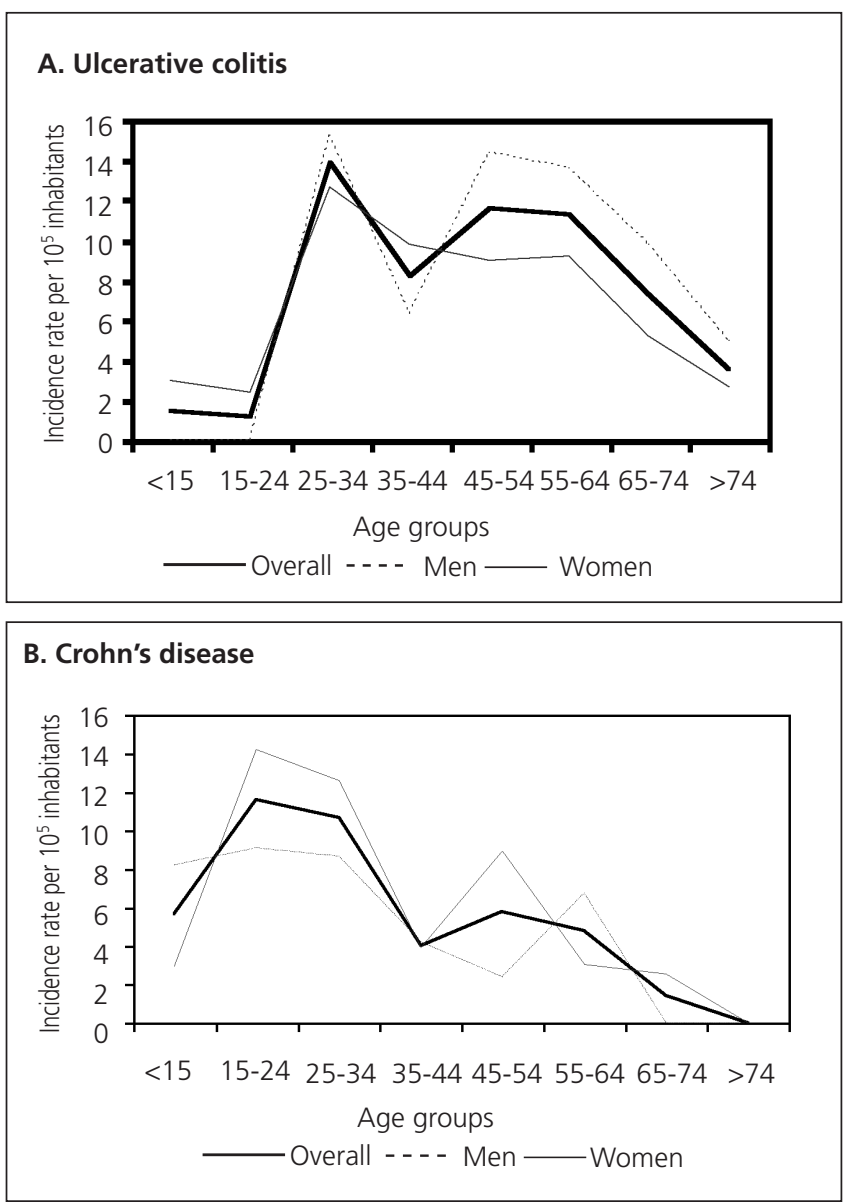

Fig. 1.- Age-specific incidence rates per 100,000 inhabitants for ulcerative colitis (A) and Crohn's disease (B).

Tasas de incidencia específicas por 100.000 de colitis ulcerosa (A), y enfermedad de Crohn (B).

$10^{5}$ inhabitants at 15-64 years reported for the Spanish study (6,7), European Collaborative study (2), and present study.
Table II. Adjusted incidence rate of UC and CD per $10^{5}$ inhabitants at 15-64 years, as reported by the European Collaborative Study on Inflammatory Bowel Disease (2), several Spanish prospective, population-based studies $(6,7)$, and the present study

\begin{tabular}{lcccccc}
\hline & Male & Female & & All \\
& Incidence 95\% Cl & Incidence 95\% Cl & Incidence 95\% Cl \\
\hline UC & & & & & & \\
Europe (2): & & & & & & \\
$\quad$ Northern & 12.5 & $10.5-14.5$ & 11.1 & $9.2-13.1$ & 11.8 & $9.0-14.6$ \\
$\quad$ Southern & 10.3 & $8.4-12.3$ & 6.9 & $5.0-8.9$ & 8.7 & $5.9-11.5$ \\
$\quad$ Spain & & & & & & \\
$\quad$ Brullet et al (6) & 9.5 & $6.8-12.2$ & 4.6 & $4.3-8.6$ & 8.0 & $6.3-9.7$ \\
$\quad$ López et al (7) & 9.2 & $7.4-11.0$ & 7.2 & $6.1-8.3$ & 7.2 & $6.1-8.3$ \\
$\quad$ Present study & 9.7 & $3.7-15.7$ & 8.5 & $3.1-14.0$ & 9.1 & $5.0-13.1$ \\
CD & & & & & & \\
Europe (2): & & & & & & \\
$\quad$ Northern & 6.2 & $4.2-8.1$ & 7.9 & $5.9-9.8$ & 7.0 & $4.2-9.8$ \\
$\quad$ Southern & 3.8 & $1.9-5.8$ & 4.0 & $2.0-6.0$ & 3.9 & $2.1-6.7$ \\
Spain & & & & & & \\
$\quad$ Brullet et al (6) & 6.0 & $3.9-8.0$ & 5.0 & $3.1-6.9$ & 5.5 & $4.1-6.9$ \\
$\quad$ López et al (7) & 4.6 & $3.4-5.8$ & 3.2 & $2.1-4.2$ & 3.9 & $3.1-4.7$ \\
$\quad$ Present study & 6.2 & $1.4-11.0$ & 8.8 & $3.2-14.4$ & 7.5 & $3.8-11.2$ \\
\hline 95\% Cl: 95\% confidence interval; UC: ulcerative colitis; CD: Crohn's disease.
\end{tabular}

At diagnosis, the extension and disease activity index of UC patients is shown in table III. In 53\% of cases, the disease was located in the left colon. Regarding CD, the most frequent phenotype according to the Vienna classification was A1L3B1 (Table IV). Four cases of CD (3 male/1 female) and 1 case of UC were registered during the study period among the population under the age of 15 ; thus, the mean incidence of CD and UC per 100,000 among these individuals was 5.7 and 1.4, respectively. The clinical characteristics of children with CD were as follows: ileum (L1) and ileocolon (L3) location in $3(75 \%)$ and $1(25 \%)$, respectively; inflammatory (B1) and penetrating (B3) behavior in $1(25 \%)$ and $3(75 \%)$, respectively; CDAI was $209 \pm 11$.

In this study, we have shown that the incidence of IBD in Oviedo, Spain, is similar to that recently described in other Spanish areas (6-8). The adjusted incidence rate per $10^{5}$ at ages between 15 and 64 years was 9.1 for $\mathrm{UC}$ and 7.5 for CD. UC was diagnosed as frequently as in other Southern European countries, whereas the incidence of $\mathrm{CD}$ was similar to that described in Northern European countries (2).

Table III. Endoscopic extension and clinical activity in patients with ulcerative colitis

\begin{tabular}{lc}
\hline Patient's characteristics \\
\hline Extension, $\mathrm{n}(\%)$ & $5(11)$ \\
$\quad$ Proctitis & $25(53)$ \\
$\quad$ Left side & $17(36)$ \\
$\quad$ Extensive colitis & $17 \pm 4$ \\
\hline
\end{tabular}




\section{Table IV. Clinical characteristics according to the Vienna classification and activity index of patients with Crohn's disease}

\begin{tabular}{cc}
\hline Patient's characteristics & \\
\hline Age, $n$ (\%) & $25(68)$ \\
$<40$ years (A1) & $12(32)$ \\
$\geq 40$ years (A2) & \\
Location, $n(\%)$ & $15(40)$ \\
Ileum (L1) & $4(11)$ \\
Colon (L2) & $18(49)$ \\
Ileocolon (L3) & \\
Behavior, $n$ (\%) & $20(54)$ \\
Inflammatory (B1) & $8(22)$ \\
Stricturing (B2) & $9(24)$ \\
Penetrating (B3) & \\
Activity index (CDAl) & $182 \pm 39$ \\
\hline
\end{tabular}

\section{DISCUSSION}

Temporal trends in the incidence rate of IBD have been documented. In Spain, a clear tendency towards increased incidence of UC and CD has been described during the last two decades. Various factors such as public access to quality medicine, the generalisation of endoscopic techniques and a better design of epidemiological studies may have influenced this. Thus, the first studies carried out in Spain were mainly based on registers of hospitalised patients and had a retrospective character, demonstrating a low incidence of IBD (1-4.8/10 \% year) (18-21). More recent prospective, population-based studies have demonstrated higher incidences $\left(8-16 / 10^{5} /\right.$ year) (6-8); the importance of the type of study is emphasized by Saro et al. (8), in whose work cases of IBD in Gijon (Spain) are collected both retrospectively (1957-1993) and prospectively (1994-1997), obtaining an incidence of 5.06 and 16.49 respectively, for these periods.

Nevertheless, in spite of the methodology previously commented, we think that the increase in the number of patients with IBD in Spain is mainly related to the socioeconomic development reached by this country in recent years. In general, there is a relationship between the incidence of IBD and the standard of life in a given country, which suggests that environmental factors may be involved, such as diet, industrialization, pollution, and economic development (1).

On using the standard European population as the reference for adjusting incidence rates we have been able to compare our results with those published using a similar methodology $(2,6,7)$; thus, we observed that the incidence of UC $\left(9.1 / 10^{5}\right)$ is similar to that described in other areas of Spain and in Southern European countries, but that it is smaller than that in countries of Northern Europe.
With regard to $\mathrm{CD}$, we found an adjusted incidence rate of 7.5/10 inhabitants, which is similar to that reported in Northern Europe and higher than in Southern areas. These data are in agreement with the existence of a European North-South gradient for UC, but no for CD.

The UC/CD ratio in our series was 1.3 , which is slightly smaller than that reported in other Spanish studies (1.4-2) (2,6-8). In Europe, this ratio is high in Scandinavian countries, given their high incidence of ulcerative proctitis (22), and in the Mediterranean area (Italy, Greece), due to their very low incidence of $\operatorname{CD}(23,24)$. A possible explanation of the low UC/CD ratio found in our study may be that ulcerative proctitis amounted to only $11 \%$, which is clearly less than the $30 \%$ communicated throughout Europe (25); we believe that the characteristics of our "health area", have been the cause that mild forms of IBD be underreported, amongst which proctitis stands out.

The overall male/female ratio in our series was 0.9 , without significant differences between UC [1] and CD [0.8]. In this respect, we wish to emphasize that the onset of $\mathrm{CD}$ was earlier in men, although the illness was more frequent in women. The age at diagnosis of patients with $\mathrm{UC}$ was greater than that of patients with $\mathrm{CD}$, similarly to reports in the medical literature (3). Regarding UC, the peak of incidence was at 25-34 years, a progressive decrease in the frequency of this disease being seen later in females, while incidence remained high in males, due to the existence of a second peak at 45-64 years; this different pattern according to gender was first demonstrated by the European Collaborative Study of IBD (2). As regards $\mathrm{CD}$, there are no large variations in the incidence according to gender, with a maximum peak of incidence at 15-34 years, and a progressive decrease with age, with a small incidence peak at 45-64 years that was previously observed in other studies $(6,7)$; on the other hand, we have already emphasized that $\mathrm{CD}$ develops ten years earlier in males than in females, a fact that explains the predominance IBD has in male children in our series.

From a clinical point of view, UC presents at diagnosis with a mild index of activity, requiring that $32 \%$ of patients are hospitalised for management; left colitis is the most frequent form of presentation, similarly to what is found by other studies (25). In 1999, the Spanish Epidemiological and Economic Study Group on Crohn's Disease published the clinical features of 635 patients with CD (26). The mean age of these patients was 33 years, $52 \%$ were women, a family history was identified in $10 \%$, and the most frequent localization of the disease was ileo-colonic involvement; our results are similar to the previous ones, with phenotype A1 (< 40 years), L3 (ileocolon location) and B1 (inflammatory behavior) being most common. Thirty-five percent of patients with CD in the Spanish epidemiological study were hospitalised during the year prior to their inclusion in the study, due to the consequences of complications (26); in our series, $32 \%$ of patients with CD were diagnosed during hospitalization. 
To our knowldge, this is the first Spanish study in which the incidence of IBD has been investigated in children. Even though the number of cases diagnosed is too small to draw definite conclusions, we deem it interesting to provide the incidence of $\mathrm{CD}$ and $\mathrm{UC}$, which was 5.7 and $1.4 / 10^{5}$ inhabitants younger than 15 years, respectively. One hundred percent of children with IBD were diagnosed between 12 and 14 years of age, which is in accord with other series in which the maximum incidence has been shown to be in this age group. Thus, Bentsen et al. (9) reported an incidence of $0.9 / 10^{5}$ in the $0-12$ years age group, and of 7.2/10 in children of 13-15 years of age. A predominance of males among children with CD has also been reported by other authors (11). Even with such a small sample size we observed a predominance of ileal and penetrating forms in children with $\mathrm{CD}$.

In summary, IBD has evolved from being a rare disease to become a relatively frequent one, with UC being slightly more common than CD. Our incidence of UC is similar to that of other countries in Southern Europe, while CD is diagnosed as frequently as in Northern countries. Clinical behaviour at diagnosis, both in terms of disease activity and disease extension and localization, is similar to that observed in the rest of Europe. IBD in Spanish children is relatively frequent, this having been most commonly observed in males. Nevertheless, larger studies are necessary in order to assess the epidemiology of IBD in this population group. With the results obtained in the present study, a better scheduling of health resources to treat this frequent gastrointestinal disease is now possible.

\section{REFERENCES}

1. Fiocchi C. Inflammatory bowel disease: etiology and pathogenesis. Gastroenterology 1998; 115: 182-205.

2. Shivananda S, Lennard-Jones J, Logan R, Fear N, Price A, Carpenter $\mathrm{L}$, et al. Incidence of inflammatory bowel disease across Europe: Is there a difference between north and south? Results of the European collaborative study on inflammatory bowel disease. Gut 1996; 39 : 690-7.

3. Russel MGVM, Stockbrügger RW. Epidemiology of inflammatory bowel disease: an update. Scand J Gastroenterol 1996; 31: 417-27.

4. Sonnenberg A, McCarty DJ, Jacobsen SJ. Geographic variation of inflammatory bowel disease within the United States. Gastroenterology 1991; 100: 143-9.

5. Blanchard JF, Bernstein CN, Wajda A, Rawsthorne P. Small-area variations and sociodemographic correlates for the incidence of Crohn's disease and ulcerative colitis. Am J Epidemiol 2001; 154: 328-35.

6. Brullet E, Bonfill X, Urrútia G, Ruiz-Ochoa V, Cueto M, Clofent J, et al. Estudio epidemiológico sobre la incidencia de enfermedad inflamatoria intestinal en cuatro áreas españolas. Med Clin (Barc) 1998; 110: 651-6.
7. López-Miguel C, Sicilia B, Sierra E, López-Zaborras J, Arribas F, Gomollón F. Incidencia de la enfermedad inflamatoria intestinal en Aragón: resultados de un estudio prospectivo poblacional. Gastroenterol Hepatol 1999; 22: 323-8.

8. Saro-Gismera C, Lacort-Fernández M, Argüelles-Fernández G, Antón-Magarzo J, García-López R, Navascués CA, et al. Incidencia y prevalencia de la enfermedad inflamatoria intestinal en Gijón (Asturias). Gastroenterol Hepatol 2000; 23: 322-7.

9. Bentsen BS, Moum B, Ekbom A. Incidence of inflammatory bowel disease in children in southeastern Norway: a prospective populationbased study 1990-94. Scand J Gastroenterol 2002; 37: 540-5.

10. Lindberg E, Lindquist B, Holmquist L, Hildebrand H. Inflammatory bowel disease in children and adolescents in Sweden, 1985-1995. J Pediatr Gastroenterol Nutr 2000; 30: 259-64

11. Armitage E, Drummond HE, Wilson DC, Ghosh S. Increasing incidence of both juvenile-onset Crohn's disease and ulcerative colitis in Scotland. Eur J Gastroenterol Hepatol 2001; 13: 1439-47.

12. Bernstein CN, Papineau N, Zajaczkowski J, Rawsthorne P, Okrusko G, Blanchard JF. Direct hospital costs for patients with inflammatory bowel disease in a Canadian tertiary care university hospital. Am J Gastroenterol 2000; 95: 677-83.

13. Bodger K. Cost of illness of Crohn's disease. Pharmacoeconomics 2002; 20: 639-52

14. Lennard-Jones JE. Classification of inflammatory bowel disease. Scand J Gastroenterol 1989; 24 (Supl. 170): 2-6.

15. Truelove SC, Witts C. Cortisone in ulcerative colitis. Final report on a therapeutic trial. Br Med J 1955; 2: 1041-8.

16. Best WR, Becktel JM, Singleton JW, Kern F Jr. Development of a Crohn's disease activity index. National Cooperative Crohn's Disease Study. Gastroenterology 1976; 70: 439-44.

17. Gasche C, Scholmerich J, Brynskov J, D’Haens G, Hanauer SB, Irvine EJ et al. A simple classification of Crohn's disease: report of the Working Party for the World Congresses of Gastroenterology, Vienna 1998. Inflamm. Bowel Dis 2000; 6: 8-15.

18. Ruiz V. Estudio epidemiológico de la enfermedad de Crohn en Galicia en el período de 1976 a 1983. Rev Esp Enferm Dig 1984; 66 : 572-3.

19. Solá R, Garcia-Puges AM, Monés J, Badosa C, Badosa J, Casellas F et al. Enfermedad inflamatoria crónica intestinal en Cataluña (Barcelona y Gerona). Rev Esp Enferm Dig 1992; 81: 7-14.

20. Martínez-Salmerón JF, Rodrigo M, de Teresa J, Nogueras F, GarcíaMontero M, de Sola C, et al. Epidemiology of inflammatory bowel disease in the Province of Granada, Spain: a retrospective study from 1979 to 1988 . Gut $1993 ; 34: 1207-9$.

21. Mate-Jimenez J, Muñoz S, Vicent D, Pajares JM. Incidence and prevalence of ulcerative colitis and Crohn's disease in urban and rura areas of Spain 1981-1988. J Clin Gastroenterol 1994; 18: 27-32.

22. Kildebo S, Nordgaard K, Aronse O, Breckan R, Burhol PG, Jorde R. The incidence of ulcerative colitis in Northern Norway from 1983 to 1986. The Northern Norwegian Gastroenterology Society. Scand J Gastroenterol 1990; 25: 890-6.

23. Tsianos EV, Masalas M. Incidence of inflammatory bowel disease in Northwest Greece: rarity of Crohn's disease in an area where ulcerative colitis is common. Gut 1994; 35: 369-72.

24. Tragnone A, Corrao G, Miglio F, Caprilli R, Lanfranchi GA. Incidence of inflammatory bowel disease in Italy: a nation-wide populationbased study. Gruppo Italiano per lo Studio del Colon e del Retto (GISC). Int J Epidemiol 1996; 25: 1044-52.

25. Lennard-Jones JE, Shivananda S, and the RC-IBD Study Group. Clinical uniformity of inflammatory bowel disease at presentation and during the first year of disease in the North and the South of Europe. Eur J Gastroenterol Hepatol 1997; 9: 353-9.

26. Spanish Study Group on Crohn's disease. Epidemiological and clinical features of Spanish patients with Crohn's disease. Eur J Gastroenterol Hepatol 1999; 11: 1121-7. 


\title{
Incidencia de la enfermedad inflamatoria intestinal (EII) en población general en el área de Oviedo
}

\author{
L. Rodrigo, S. Riestra ${ }^{1}$, P. Niño, V. Cadahía, R. Tojo, D. Fuentes, M. Moreno, E. González-Ballina \\ y E. Fernández²
}

Servicio de Aparato Digestivo. Hospital Universitario Central de Asturias. ${ }^{I}$ Sección de Aparato Digestivo. Hospital Valle del Nalón. Asturias. ${ }^{2}$ Servicio de Bioquímica. Hospital de Cabueñes. Gijón

\section{RESUMEN}

Objetivo: conocer la incidencia de enfermedad inflamatoria intestinal en el área de Oviedo y describir las características clínicas de los nuevos pacientes.

Pacientes y métodos: estudio prospectivo poblacional en el Área Sanitaria IV del Principado de Asturias (Oviedo, 312.324 habitantes). Fueron registrados todos los pacientes nuevos diagnosticados de enfermedad inflamatoria intestinal en un periodo de 2 años consecutivos.

Resultados: se incluyeron un total de 85 pacientes, 47 con colitis ulcerosa (CU), 37 con enfermedad de Crohn (EC) y 1 con colitis indeterminada (CI). La tasa de incidencia ajustada por $10^{5}$ habitantes entre 15 y 64 años, de CU y EC, fue de 9,1 para CU (IC95\%: 5-13,1) y 7,5 para la EC (IC95\%: 3,8-11,2). La proporción hombre/mujer fue de 0,9 , sin diferencias significativas entre ambas enfermedades. Los pacientes con EC eran más jóvenes que los que tenían CU (33 \pm 15 años vs $45 \pm 20$ años; $p<0,05)$. La mayor parte de los pacientes con EC tenían menos de 35 años (65\%), mientras que los que presentaban CU fueron diagnosticados entre los 25 y 64 años (81\%).

La extensión endoscópica de la CU fue: rectal en el 11\%; colon izquierdo en el 53\% y extensa en el 36\%. Respecto a la EC, predominó la forma mixta o íleo-cólica (49\%), seguida por la ileal (40\%) y la colónica (11\%). El patrón inflamatorio, estenótico y fistuloso, se presentó en el 54, 22 y $24 \%$ de los casos de EC, respectivamente.

Conclusiones: en nuestra área, la incidencia de EC es similar a la descrita en países del Norte de Europa, mientras que la de la $\mathrm{CU}$, es ligeramente inferior. La EC afecta principalmente a personas jóvenes, mientras que la $\mathrm{CU}$ predomina en personas de mediana edad. Al diagnóstico, la CU se encuentra fundamentalmente localizada, mientras que los pacientes con EC presentan una forma íleo-cólica y un patrón inflamatorio, de forma predominante.

Palabras clave: Enfermedad inflamatoria intestinal. Colitis ulcerosa (CU). Enfermedad de Crohn (EC). Incidencia. Epidemiología. España.

\section{INTRODUCCIÓN}

La enfermedad inflamatoria intestinal (EII) es un término genérico que incluye la enfermedad de Crohn (EC), la colitis ulcerosa $(\mathrm{CU})$ y la colitis indeterminada (CI).
Las causas de estas enfermedades no son bien conocidas, pero una predisposición genética y diversos factores ambientales están implicados en su etiología y patogenia (1). En general, los estudios poblacionales han mostrado que la incidencia de CU y EC es mayor en latitudes nórdicas $(2,3)$; además, existe evidencia de variaciones epidemiológicas dentro de un mismo país (4). Estas diferencias pueden resultar de variaciones en las características socio-demográficas de las poblaciones (5), más que de un diferente origen genético. En España, varios estudios prospectivos poblacionales han mostrado una frecuencia variable de EII (8-16 casos por 100.000 habitantes/año) (6-8). Estos resultados coinciden con los del estudio colaborativo europeo sobre enfermedad inflamatoria intestinal, el cual encontró que la diferencia en la incidencia de EII entre áreas del Norte y Sur de Europa era menor de los esperado (2).

La mayoría de los estudios de EII han sido realizados en adultos y ha habido pocos estudios prospectivos poblacionales en niños (9). Existen datos contradictorios sobre la tendencia temporal de la incidencia de la EII de inicio juvenil (9-11). En España, la incidencia de EII en niños menores de 15 años es desconocida.

Actualmente, el manejo de los pacientes con EII está asociado con un importante consumo de recursos sanitarios, tanto en cuanto a visitas médicas, hospitalización, cirugía, tratamientos crónicos, terapias biológicas, etc. $(12,13)$. Por otra parte, a la vista de la complejidad de estas enfermedades, se ha precisado una aproximación multidisciplinar (gastroenterólogos, cirujanos, dietistas, etc.) y se han creado unidades monográficas para atender a este tipo de pacientes. Por tanto, con vistas a planificar los recursos sanitarios, es de gran interés el conocer la incidencia de EII.

El objetivo de este estudio fue determinar la incidencia de EII en la población general de Oviedo (Principado de Asturias, España), y recoger las características fenotípicas de los nuevos pacientes diagnosticados durante un periodo de 2 años. Además, describimos la forma de presentación de la EII en niños. 


\section{PACIENTES Y MÉTODOS}

\section{Diseño del estudio}

Realizamos un estudio prospectivo y descriptivo en la población general (312.324 habitantes, 75\% urbanos) del Área sanitaria IV del Principado de Asturias. El hospital de referencia para esta población es el Hospital Universitario Central de Asturias (Oviedo). El periodo de inclusión fue desde septiembre del 2000 hasta septiembre del 2002.

Se estableció un protocolo de estudio, que fue enviado a todos los médicos de Atención Primaria, pediatras y especialistas en Aparato Digestivo y Cirugía General del Área Sanitaria. Además, celebramos varias reuniones informativas, antes y durante el periodo de estudio. El objetivo era que todos los pacientes con sospecha diagnóstica de EII fueran enviados al centro de referencia, para que el diagnóstico fuese confirmado y fuesen registrados en el protocolo de estudio.

\section{Pacientes con EII}

Todos los casos fueron evaluados en el Hospital Universitario Central de Asturias, en una consulta externa dedicada a atender pacientes con EII (pacientes ambulatorios). Por otra parte, los pacientes que habían sido ingresados por primera vez con sospecha de EII, y diagnosticados como nuevos casos durante el periodo de estudio, fueron también incluidos (pacientes hospitalizados). No hubo ninguna restricción de edad.

Basalmente a todos los sujetos se les practicó una evaluación completa, que incluía datos demográficos y clínicos, exploración física y estudios analíticos (hemograma, coagulación y bioquímica general). También se determinaron reactantes de fase aguda, tales como la velocidad de sedimentación globular, la proteína $\mathrm{C}$ reactiva y el ácido orosomucoide. Se realizó colonoscopia y/o estudio radiológico con bario del intestino delgado, y se tomaron biopsias intestinales, con vistas a completar el diagnóstico y a evaluar la extensión de la enfermedad. Basándonos en los resultados de los estudios practicados, los pacientes eran registrados o no como pacientes con EII; los criterios clásicos de Lennard-Jones para la EC (14) y de Truelove-Witts para la CU (15) fueron estrictamente aplicados. Las revisiones fueron programadas de forma individualizada, según la situación clínica de cada paciente.

Varios índices específicos de actividad fueron calculados, basalmente y en cada visita, con vistas a evaluar la intensidad de los síntomas $(15,16)$. Con objeto de describir la expresión fenotípica de la EC usamos la clasificación de Viena (17), la cual incluye la edad al diagnóstico (A1 = menor de 40 años; A2 = igual o mayor de 40 años), la localización $(\mathrm{L} 1$ = 1́leon terminal; L2 = colon; L3 = 1́leo-cólica; L4 = tracto digestivo alto) y el comportamiento clínico (B1 = inflamatorio; $\mathrm{B} 2$ = estenosante y B3 = fistuloso).

\section{Análisis estadístico}

Un paciente con colitis indeterminada fue excluido del estudio. Las tasas de incidencia medias anuales de EC y CU fueron calculadas como número de nuevos casos por 100.000 habitantes y año. Usamos el método directo de estandarización para ajustar las tasas de incidencia, por edad (15-64 años) y sexo, a la población estándar europea. Los intervalos de confianza (IC) para las tasas de incidencia eran calculadas con un nivel de probabilidad del 95\%, usando la distribución de Poisson o la distribución normal. Las proporciones fueron comparadas usando la prueba exacta de Fisher, considerándose significativa con un valor de $\mathrm{p}<0,05$ ( 2 colas).

\section{RESULTADOS}

Se diagnosticaron un total de 85 pacientes con EII durante los 2 años que duró el periodo de inclusión, de los cuales 47 tuvieron CU, 37 EC y 1 colitis indeterminada. La proporción CU/EC fue 1,3. 28 pacientes (33\%) fueron diagnosticados durante su ingreso por síntomas gastrointestinales severos (pacientes hospitalizados), sin diferencias entre ambas enfermedades. Cuarenta pacientes eran hombres $(\mathrm{H})$ y 44 mujeres $(\mathrm{M})$, con una proporción $\mathrm{H} / \mathrm{M}$ de 0,9 . La edad media fue de $39 \pm 18$ años (rango 12-91 años), sin diferencias significativas según el sexo (36 \pm 17 en hombres y $32 \pm 17$ en mujeres). Las características generales basales de los pacientes con EII se muestran en la tabla I; al comparar los pacientes con CU y con EC, sólo se encontraron diferencias en cuanto a la edad (pacientes con EC eran más jóvenes que los que padecían CU) $(p<0,05)$.

Tabla I. Características generales de los pacientes con colitis ulcerosa y enfermedad de Crohn

\begin{tabular}{lcc}
\hline & $\begin{array}{c}\text { Colitis ulcerosa } \\
(n=47)\end{array}$ & $\begin{array}{c}\text { Enfermedad Crohn } \\
(n=37)\end{array}$ \\
\hline Edad & $45 \pm 20$ & $33 \pm 15^{*}$ \\
Sexo & & \\
$\quad$ Hombres & 24 & 16 \\
Mujeres & 23 & 21 \\
$\quad$ Proporción H/M & 1 & 0,8 \\
Hospitalizados al diagnóstico, $15(32)$ & $13(35)$ \\
$\quad$ n (\%) & & \\
Factores de riesgo: & $9(19)$ & $8(22)$ \\
Amigdalectomía, n (\%) & $4(9)$ & $3(8)$ \\
Apendicectomía, n (\%) & $19(40)$ & $17(46)$ \\
Fumadores, n (\%) & $13(28)$ & $9(24)$ \\
Tomadores AINE, n (\%) & $9(24)$ \\
Tomadores ACO, n (\%) & $12(26)$ & $4(11)$ \\
Ell en familiares, n (\%)* & $1(2)$ & \\
\hline
\end{tabular}

${ }^{*} \mathrm{p}<0.05$

H/M: hombres/mujeres; AINE: anti-inflamatorios no esteroideos; ACO: anticonceptivos orales; Ell: enfermedad inflamatoria intestinal. 
Las tasas de incidencia media anuales de $\mathrm{CU}$ y de EC fueron 7,5 y 5,9 por $10^{5}$ habitantes, respectivamente. La figura 1 muestra las tasas de incidencia globales específicas por edad y sexo, para ambas enfermedades. La mayoría de los pacientes con $\mathrm{EC}$ fueron diagnosticados antes de los 35 años de edad (65\%), con una disminución de las tasas, en ambos sexos, según se incrementaba la edad; observamos un pequeño aumento de la incidencia en mujeres entre 45-54 años y en hombres entre 55-64 años. Respecto a la CU, observamos distintos patrones de incidencia en hombres y mujeres, con un pico de incidencia en mujeres entre 25-34 años, mientras que en los hombres había dos picos de incidencia, entre 25-34 y 45-64 años. La tabla II muestra las tasas de incidencia ajustadas por $10^{5}$ habitantes entre 15-64 años, de CU y EC comunicadas en los estudios españoles $(6,7)$, en el estudio colaborativo europeo (2) y en el trabajo actual.

\begin{tabular}{|c|c|c|c|c|c|c|}
\hline \multirow[b]{2}{*}{$C U$} & \multicolumn{2}{|c|}{$\begin{array}{c}\text { Hombres } \\
\text { Incidencia IC95\% }\end{array}$} & \multicolumn{2}{|c|}{$\begin{array}{c}\text { Mujeres } \\
\text { Incidencia IC95\% }\end{array}$} & \multicolumn{2}{|c|}{$\begin{array}{c}\text { Todos } \\
\text { Incidencia /C95\% }\end{array}$} \\
\hline & & & & & & \\
\hline Europa (2): & & & & & & \\
\hline Norte & 12,5 & $10,5-14,5$ & 11,1 & $9,2-13,1$ & 11,8 & $9,0-14,6$ \\
\hline . Sur & 10,3 & $8,4-12,3$ & 6,9 & $5,0-8,9$ & 8,7 & $5,9-11,5$ \\
\hline \multicolumn{7}{|l|}{ España } \\
\hline Brullet et al (6) & 9,5 & $6,8-12,2$ & 4,6 & $4,3-8,6$ & 8,0 & $6,3-9,7$ \\
\hline López et al (7) & 9,2 & $7,4-11,0$ & 7,2 & $6,1-8,3$ & 7,2 & $6,1-8,3$ \\
\hline Estudio actual & 9,7 & $3,7-15,7$ & 8,5 & $3,1-14,0$ & 9,1 & $5,0-13,1$ \\
\hline \multicolumn{7}{|l|}{$E C$} \\
\hline \multicolumn{7}{|l|}{ Europa (2): } \\
\hline Norte & 6,2 & $4,2-8,1$ & 7,9 & $5,9-9,8$ & 7,0 & $4,2-9,8$ \\
\hline $\begin{array}{l}\text { Sur } \\
\text { España }\end{array}$ & 3,8 & $1,9-5,8$ & 4,0 & $2,0-6,0$ & 3,9 & $2,1-6,7$ \\
\hline Brullet et al (6) & 6,0 & $3,9-8,0$ & 5,0 & $3,1-6,9$ & 5,5 & $4,1-6,9$ \\
\hline López et al (7) & 4,6 & $3,4-5,8$ & 3,2 & $2,1-4,2$ & 3,9 & $3,1-4,7$ \\
\hline Estudio actual & 6,2 & $1,4-11,0$ & 8,8 & $3,2-14,4$ & 7,5 & $3,8-11,2$ \\
\hline
\end{tabular}

IC95\%: intervalo confianza 95\%; CU: colitis ulcerosa; EC: enfermedad Crohn.

La tabla III muestra la extensión y el índice de actividad de la enfermedad en pacientes con CU, al diagnóstico de la misma. En el 53\% de los casos, la enfermedad afectaba al colon izquierdo. En cuanto a la EC, el fenotipo más frecuente según la clasificación de Viena fue el A1L3B1 (Tabla IV). Durante el periodo de estudio, registramos 4 casos de EC ( 3 hombres/1 mujer) y 1 caso de CU entre personas menores de 15 años; así, la incidencia media por 100.000 de EC y CU entre estos sujetos fue de 5,7 y 1,4 respectivamente. Las características clínicas de los niños con EC fueron las siguientes: localización en íleon (L1) e íleo-cólica (L3) en $3(75 \%)$ y 1 (25\%), respectivamente; un patrón inflamatorio (B1) y fistuloso (B3) en $1(25 \%)$ y $3(75 \%)$, respectivamente; el CDAI fue de $209 \pm 11$.

Tabla III. Extensión endoscópica y actividad clinica de los
pacientes con colitis ulcerosa

\begin{tabular}{|c|c|}
\hline Características de los pacientes & \\
\hline $\begin{aligned} & \text { Edad, } n(\%) \\
&< 40 \text { años (A1) } \\
& \geq 40 \text { años (A2) }\end{aligned}$ & $\begin{array}{l}25(68) \\
12(32)\end{array}$ \\
\hline $\begin{array}{l}\text { Localización, n (\%) } \\
\text { Íleon (L1) } \\
\text { Colon (L2) } \\
\text { Íleo-cólica (L3) }\end{array}$ & $\begin{array}{c}15(40) \\
4(11) \\
18(49)\end{array}$ \\
\hline $\begin{array}{c}\text { Comportamiento, } n \text { (\%) } \\
\text { Inflamatorio (B1) } \\
\text { Estenosante (B2) } \\
\text { Fistulizante (B3) }\end{array}$ & $\begin{array}{l}20(54) \\
8(22) \\
9(24)\end{array}$ \\
\hline Índice de actividad (CDAI) & $182 \pm 39$ \\
\hline
\end{tabular}

\section{DISCUSIÓN}

En el presente estudio hemos encontrado que la incidencia de EII en Oviedo, es similar a la recientemente descrita en otras regiones españolas (6-8). La tasa de incidencia ajustada por 105, entre 15-64 años, fue de 9,1 para la CU y 7,5 para la EC. La CU fue diagnosticada tan frecuentemente como en otros países del sur de Europa, mientras que la incidencia de EC fue similar a la descrita en países del norte de Europa (2).

Se ha visto que existen tendencias temporales en la incidencia de EII. En España, se ha descrito una clara tendencia hacia el aumento de incidencia de CU y de EC, en las últimas dos décadas. Varios factores podrían haber influido en este aumento, como el acceso público a una medicina de calidad, la generalización de las técnicas endoscópicas y un mejor diseño de los estudios epidemiológicos. Así, los primeros estudios llevados a cabo en España, que se basaban fundamentalmente en registros de pacientes hospitalizados y tenían un carácter retrospectivo, demostraban una baja incidencia de EII (1-4,8/ 105/ año) (18-21). Los estudios más recientes, poblacionales y prospectivos, han demostrado una mayor incidencia (8-16/ 10/ año) (6-8); la importancia del tipo de diseño del estudio queda remarcado en el trabajo de Saro y cols. (8), en el que se recogieron los casos de EII en Gijón, en dos periodos de tiempo diferentes, en uno retrospectiva (1957-1993) y en otro prospectivamente (19941997), obteniendo una incidencia de 5,06 y 16,49 respectivamente. 
No obstante y a pesar de las diferencias metodológicas comentadas previamente, nosotros pensamos que el incremento en el número de pacientes con EII en España está fundamentalmente relacionado con el desarrollo socioeconómico alcanzado por el país en los últimos años. En general, hay una relación entre la incidencia de EII y el nivel de vida, lo cual sugiere que en el desarrollo del proceso pueden estar implicados factores ambientales, tales como la dieta, industrialización, contaminación y el desarrollo económico (1).

Al usar la población estándar europea como referencia para ajustar las tasas de incidencia, hemos podido comparar nuestros resultados con otros publicados que han usado una metodología similar $(2,6,7)$; así, hemos observado que la incidencia de CU $\left(9,1 / 10^{5}\right)$ es similar a la descrita en otras regiones de España y en países del sur de Europa, pero es algo menor que la vista en países del norte de Europa. Respecto a la EC, la tasa de incidencia ajustada fue de 7,5/ $10^{5}$ habitantes, la cual es similar a la comunicada en países nórdicos y mayor que la descrita en regiones del sur de Europa. Estos datos concuerdan con la existencia de un gradiente europeo Norte-Sur para la CU, pero no para la EC.

La proporción CU/EC en nuestra serie fue de 1,3, lo cual es discretamente menor que la comunicada en otros estudios españoles $(1,4-2)(2,6-8)$. En Europa, esta proporción es alta en los países escandinavos, dada la alta incidencia de proctitis ulcerosa (22) y en el área mediterránea (Italia, Grecia) debido a la muy baja incidencia de EC $(23,24)$. La posible explicación de una baja proporción CU/EC encontrada en nuestro estudio, es el $11 \%$ de proctitis ulcerosas registrado, lo cual es claramente menor que el 30\% observado en la mayoría de estudios europeos (25); creemos que las características de nuestra Área de Salud, han sido la causa de una menor comunicación de formas leves de EII, entre las cuales estarían las proctitis ulcerosas.

La relación hombres/mujeres en nuestra serie fue 0,9 , sin diferencias significativas entre CU [1] y EC $[0,8]$. En este sentido, nos gustaría resaltar que el inicio de la EC fue más precoz en hombres, si bien la enfermedad era más frecuente en mujeres. La edad al diagnóstico de los pacientes con CU fue mayor que la de los que padecían EC, al igual que lo publicado en la literatura médica (3). Con respecto a la $\mathrm{CU}$, el pico de máxima incidencia fue entre 25-34 años, con un descenso progresivo posterior entre las mujeres, mientras que en los hombres la incidencia permaneció elevada, debido a un segundo pico entre 45-64 años; este distinto patrón epidemiológico según el sexo fue demostrado por primera vez por el Estudio Colaborativo Europeo sobre la enfermedad inflamatoria intestinal (ECS of IBD) (2). Respecto a la EC, no hemos observado grandes variaciones en la incidencia entre ambos sexos, con un pico de máxima incidencia entre 15-34 años, y un descenso progresivo con la edad, junto con un pequeño pico entre 45-64 años, que ya ha sido previamente observado en otros estudios $(6,7)$; por otra parte, ya hemos resaltado que la EC debuta 10 años antes en hombres que en mujeres, lo cual explica el predominio de varones en la EII en niños en nuestra serie.

Desde un punto de vista clínico, la CU presentó al diagnóstico un índice de actividad moderado, el 32\% de los pacientes precisaron ser hospitalizados para el tratamiento del proceso y, la colitis izquierda fue la forma de presentación más frecuente, al igual que lo que ocurre en otros estudios (25). En 1999, el Grupo Español para el Estudio Epidemiológico y Económico de la Enfermedad de Crohn publicó los hallazgos clínicos de 635 pacientes con EC (26). La edad media de los pacientes fue de 33 años, el $52 \%$ eran mujeres, un $10 \%$ tenían antecedentes familiares y la localización más frecuente de la enfermedad fue la afectación íleo-cólica; nuestros resultados coinciden con los anteriores, siendo el fenotipo más frecuente el A1 (< 40 años), L3 (localización íleo-cólica) y B1 (patrón inflamatorio). El $35 \%$ de los pacientes con EC, en el estudio epidemiológico español, fueron hospitalizados durante el año previo a la inclusión en el mismo, como consecuencia de complicaciones de la enfermedad (26); en nuestra serie, el 32\% de los pacientes fueron diagnosticados durante su ingreso hospitalario.

Este es el primer estudio español en el que se ha investigado la incidencia de EII en niños. Aunque el número de casos diagnosticados es demasiado pequeño para poder extraer conclusiones definitivas, pensamos que es interesante aportar los datos de incidencia de la EC y CU en niños (5,7 y 1,4/10 habitantes menores de 15 años, respectivamente). El $100 \%$ de los niños con EII fueron diagnosticados entre 12 y 14 años de edad, lo cual coincide con otras series, en las cuales la máxima incidencia de la enfermedad era en este grupo de edad. Así, Bentsen y cols. (9), encontraron una incidencia de $0,9 / 10^{5}$ en el grupo de 0-12 años y de 7,2/10 en niños de 13-15 años. El predominio de varones en la EC de niños, también ha sido observado por otros autores (11). Con la limitación del tamaño de la muestra, también hemos observado un predominio de las formas con afectación ileal y con un patrón fistulizante en niños con EC.

En resumen, la EII ha pasado de ser una enfermedad rara a ser relativamente frecuente, siendo la CU ligeramente más frecuente que la EC. La incidencia de CU es similar a la descrita en otros países del sur de Europa, mientras que la EC es diagnosticada tan frecuentemente como en países nórdicos. El comportamiento clínico, tanto en cuanto a la actividad de la enfermedad como a la extensión y localización de la misma, es igual que el observado en el resto de Europa. La EII en niños espanoles es relativamente frecuente siendo observada sobre todo en varones. No obstante, son necesarios estudios con un mayor número de casos para conocer la epidemiología de la enfermedad en este grupo de población. Con los resultados obtenidos en el presente estudio, será posible planificar mejor los recursos sanitarios con el objeto de ser capaces de tratar esta frecuente enfermedad digestiva. 